\title{
A TRADIÇÃO CRISTÁ E A VALORIZAÇÃO DA ORIGEM JUDAICA DE FIGURAS DA POESIA ROMÂNTICA BRASILEIRA
}

\author{
Daniel Santana de Jesus*
}

Resumo: Este trabalho tem por objetivo discutir o fenômeno da valorização da origem judaica de figuras da poesia romântica brasileira, mesmo em presença de elementos da tradição cristã. Em várias passagens deste trabalho, tal postura será, no entanto, sempre relativizada quando se notarem ambigüidades.

Palavras-chave: Literatura brasileira, Cristianismo, figura judia.

Abstract: This article aims to investigate the valorization of Jewish origin of personae of Brazilian romantic poetry, yet before elements of Christian tradition. However, this approach is going to be relativized in any element that it notices ambiguities.

Keywords: Brazilian literature, Christianity, Jewish persona.

O sentimento de hostilidade em relação aos judeus existe desde antes da origem do cristianismo, mas foi especialmente estimulado pela influência da Igreja Católica na Idade Média. Apesar de mais brando do que em seu vizinho ibérico, o sentimento de ojeriza em relação ao judeu também existia em Portugal. Tal disposição piorou muito depois da imigração dos judeus expulsos da Espanha em 1492. Por fim, o rei D. Manuel publicaria um édito de expulsão dos judeus em 1496. Com a colonização portuguesa o Brasil teria herdado essa antipatia pelo judeu. $\mathrm{O}$ projeto de pesquisa de Iniciação Científica "O retrato do judeu pelo escritor romântico brasileiro" considerou esse pressuposto ao verificar qual o tratamento dispensado ao judeu em obras poéticas e romances do Romantismo brasileiro ${ }^{1}$. Com o intuito de discernir se a caracterização do judeu leva em conta apenas sua especificidade étnica ou

\footnotetext{
* Mestrando do Programa de Pós-Graduação em Língua Hebraica, Literatura e Cultura Judaicas do Departamento de Letras Orientais da FFLCH - USP.

1. Este projeto foi desenvolvido entre o segundo semestre de 2002 e o segundo semestre de 2005. Durante todo esse tempo, foi financiado pelo Programa Institucional de Bolsas de Iniciação Científica PIBIC/ CNPq /USP. Ele estava inserido em dois projetos maiores liderados pela professora Berta Waldman: "A Cultura no Plural: Representações de não-nacionais na Literatura Brasileira" e "A representação do judeu na literatura brasileira”. Por fim, os dados identificados nesta pesquisa estão em processo de publicação.
} 
seu status comum de não-nacional, foram coletados também dados referentes aos estrangeiros.

Verificaram-se estereótipos negativos na caracterização de mais da metade das quatorze personagens judias identificadas nos romances. Mas a maior parte das vinte e sete figuras ${ }^{2}$ judias identificadas nas obras poéticas recebe tratamento positivo. Algumas delas têm traços de sua origem judaica enaltecidos mesmo quando são identificados no texto elementos da tradição religiosa cristã. A seguir, será comentada a representação das três figuras judaicas em que se verifica esse fenômeno.

\section{Hostilidade dos judeus em relação aos primeiros cristãos}

Nos Evangelhos e em Atos dos Apóstolos, livros presentes na Bíblia Cristã, há diversas passagens em que os cristãos primitivos são perseguidos pelos judeus. $\mathrm{O}$ topos da hostilidade do judeu contra a religião cristã está presente no poema "O renegado: canção do judeu", de Junqueira Freire (1944). Neste texto, um judeu, profundamente desgostoso com a adesão de seu filho ao cristianismo, desqualifica essa religião na medida em que a concebe como uma violência contra o judaísmo, de tradição muito mais antiga:

"E agora, meu filho,

Nas tábuas cuspindo,

Nos deixa sorrindo" (Idem: p. 129)

A palavra "tábuas" refere-se às famosas duas tábuas contendo os dez mandamentos entregues ao líder hebreu ${ }^{3}$ Moisés, segundo a tradição presente no livro bíblico de Exxodo. O momento da entrega dessas tábuas a Moisés marca o surgimento da lei religiosa judaica. Assumindo-se que "tábuas" é metonímia da tradição religiosa judaica, o filho do judeu que fala no poema estaria cometendo um sacrilégio ao cuspir nelas.

Se esse cristão recém-convertido é representado como um sacrílego pelo $t u$ do poema, por ofender um símbolo do judaísmo, pode-se depreender uma representação positiva, por esse mesmo $t u$, quando são os judeus a agredir um símbolo do cristianismo.

2. Uma vez que, para os fins de coleta de dados desta pesquisa, a definição de personagem se mostrou problemática nas obras poéticas, foi utilizado o termo "figura". Já o termo "personagem" se manteve para os dados dos romances.

3. "Hebreu" é a denominação dada ao povo judeu em um estágio muito anterior de sua consciência como povo distinto, como nação. 
"E os nossos rabinos,

Com a raiva do velho,

O falso evangelho

Pisaram aos pés" (Ibidem).

Nos versos transcritos acima, a imagem sugerida pelo termo "evangelho" é a de um volume contendo os textos canônicos cristãos, também conhecidos como Novo Testamento. O volume sagrado é lançado ao chão e pisoteado pelos rabinos. Desta forma, pode-se considerar "evangelho" como metonímia do cristianismo nesse trecho do poema. Mas uma possível leitura do poema propicia verificar que a atitude dos rabinos não é representada como sacrílega por ofender um símbolo cristão. No verso "Com a raiva do velho" pode-se deduzir uma cólera vista como justa se se assumir o epíteto "velho" como figura de linguagem que denota autoridade (lembremos do dito que exorta a "respeitar as cãs" dos mais velhos). Estendendo o alcance do sentido dessa figura do velho, o episódio da agressão ao volume do evangelho pelos rabinos denotaria uma justa cólera dos guardiões de uma tradição muito antiga em relação ao cristianismo, representado como uma heresia mais recente.

Essa valorização da antiguidade da tradição judaica em um contexto cristão teria origem no fato de que o cristianismo teria se apropriado dessa antiguidade ao interpretar o judaísmo como um "protocristianismo". A religião cristã interpreta o conteúdo da Bíblia Judaica como uma etapa anterior do próprio cristianismo. Essa religião suplantaria o judaísmo por ser uma realização, um aperfeiçoamento do mesmo. Tanto que a Bíblia Judaica é designada no cânone cristão por Antigo Testamento, e os textos produzidos já pelos cristãos, Novo Testamento. ${ }^{4}$

Em seu artigo "Figura", Erich Auerbach contribuiu para a investigação dessa apropriação cristã do cânone judaico. $O$ autor trata com bastante detalhe o desenvolvimento de um método de interpretação da Bíblia Judaica pelos Pais da Igreja que leva ao apagamento de seu conteúdo histórico, tornando-se o mesmo apenas índice de acontecimentos importantes do Novo Testamento. No limite do alcance do processo de desistoricização latente nesse método de interpretação, a história judaica presente no Antigo Testamento torna-se uma fase da História, esta vista como uma alegoria maior: na primeira, tem-se a história do povo judeu até seu apogeu com a primeira vinda de Cristo; na segunda, a Encarnação de Cristo é alegoria dos acontecimentos previstos para o Juízo Final; com o Juízo Final temos o fim da História dentro dessa interpretação cristã (Auerbach: 1997, p. 36). Esse estudo de Auerbach foi fundamental para o trabalho de Marczyk, Representações

4. A respeito desse ponto de escatologia cristã, lerei alguns capítulos de A teologia do apóstolo Paulo de James D. G. Dunn. 
cristãs de tipos judeus em As minas de prata, de José de Alencar (2006). Também tem sido importante para minha atual pesquisa, mais especificamente para a investigação do destino previsto para o povo judeu no Juízo Final segundo a teologia cristã.

Por fim, devo relativizar essa percepção de uma caracterização positiva de elementos da tradição judaica no poema, pois há uma passagem em que o judeu assume para seu povo um estereótipo, negativo em muitos contextos. Durante o período do exílio dos judeus, do século I d.C a 1948, surgiu na Idade Média a figura mítica do Judeu Errante, condenado a vagar pela terra sem descanso. Por sua vez, essa imagem tem paralelos com a de Caim ${ }^{5}$. Ele matou Abel e foi condenado por Deus a vagar também sem descanso pela terra (Gênesis 4:1-16):

"Talvez mais que os nossos,

Irás, vagabundo,

De rastros no mundo,

Sem termo, sem fim!

Nas selas, nas côrtes

Os homens com gosto

Lerão em teu rosto

Sinal de Caim." (Idem: p. 125).

Ao se notar tal elemento relativizador de uma caracterização positiva do judeu, poder-se-ia ainda pensar na viabilidade de uma leitura engajada religiosamente que percebesse nas imprecações do velho rabino contra o cristianismo não uma atitude de justa cólera, mas a de alguém bastante resistente a uma religião vista como a verdadeira.

\section{Identidade judaica em cenas dos Evangelhos}

"Uma pobre mulher corrida e quase nua

Deita-te aos pés, Jesus, o clarão de uma lua.

Ela acolheu-se a ti e nela a formosura!

Que abismos nessa carne, e que luz nessa alvura!

Canta invisível nela um sol; ouço-lhe o trilo.

Não é Vênus de Cós, não é Vênus de Milo:

É Vênus de outro mar, é deusa de outra espuma.

\footnotetext{
5. Essa associação entre o exílio do povo judeu e a maldição de Caim é explícita no poema narrativo "Improbus amor" de Frederico José Correia. Este texto é a fonte de primeira mão de minha pesquisa de mestrado, em que procuro descrever o papel de diversos elementos sombrios que aparecem no poema - entre eles a condição judaica vista como maldita - no destino trágico de todas as personagens judias de seu enredo.
} 
Bela, não se parece enfim com deusa alguma:

É o belo-ideal fundido de outra idéia:

Prometeu desta vez roubando a luz divina

Coalhou-a, como pode e ninguém imagina,

E fez dela o ideal da mulher da Judéia..." (Delfino: 2001, II, p. 727).

O trecho acima foi extraído do poema "O Cristo e a adúltera", do poeta catarinense Luiz Delfino. Na cena do Evangelho retratada nele, Cristo livra uma mulher adúltera de ser apedrejada por religiosos judeus representados como radicais e hipócritas (João 8: 3-11). Não há nessa passagem do Evangelho de João qualquer menção ao nome da personagem. No poema ela é chamada de Maria Madalena. $\mathrm{Na}$ verdade, a figura de Maria Madalena que chegou até nossos dias teria sido trabalhada a partir de uma fusão de três mulheres presentes nos Evangelhos: a própria Maria Madalena, uma mulher que lavou os pés de Cristo com perfume e secou-os com os cabelos (Lucas 7:37-50) e a já referida mulher adúltera. Também não há nos evangelhos qualquer menção à beleza física dessa mulher adúltera. Mas no poema sua beleza é extremamente idealizada, um padrão de beleza para a mulher judia. Na pesquisa relativa ao projeto " $\mathrm{O}$ retrato do judeu pelo escritor romântico brasileiro" verifiquei grande recorrência de uma caracterização idealizada da beleza da mulher judia a partir de modelos extraídos de textos bíblicos como Ester, Gênesis e Cântico dos Cânticos. Celso Lafer já tinha identificado esse fenômeno ao estudar a representação do judeu em Gil Vicente (1978: 77-78).

Apesar de eu discorrer sobre o tratamento positivo da figura judia mesmo em presença de elementos da tradição religiosa cristã, é importante atentar para uma postura extremamente laica de Luiz Delfino na caracterização de Maria Madalena. Tal atitude estaria embasando a sugestão, entre outras bastante distantes de um típico comedimento cristão, mesmo de uma atração sexual de Jesus Cristo por Maria Madalena no poema em questão (Delfino: op. cit., II, p. 733-734): Não a deixes guardar a incômoda atitude [Maria Madalena está ajoelhada diante de Cristo]:/ Ó Cristo, embora irado um pouco ainda, eu vejo,/ Que há em todo o teu corpo um frêmito... um desejo... ${ }^{6}$

6. Eu gostaria muito de associar essa atitude laica de Luiz Delfino com aquela tributária de um peculiar desenvolvimento da sensibilidade erótica no romantismo e no decadentismo europeus descrito por Mario Praz em A carne, a morte e o diabo na literatura romântica. Há na obra de Delfino dos Santos até um poema em que a descrição da beleza de Cristo atinge claramente traços andróginos (op. cit., I, p. 128). Mas, a meu ver, para 


\section{Fontes judaicas em símbolos cristãos}

Maria, mãe de Cristo, é um dos maiores símbolos do cristianismo, pelo menos em sua vertente católica. Essa figura é extremamente valorizada, apesar de ser muito pouco referida nos Evangelhos, em comparação com a figura de Jesus e a de alguns apóstolos. No poema "Stella Matutina", de Fagundes Varela (1970: p. 6364), em meio à exaltação religiosa de Maria, vista em expressões como "Princesa Divina", "Santa esposa de José" e "Sacrossanta padroeira", há também a exaltação de sua beleza, como nos versos:

"Como és bela!

Mais belas não eram não.[,]

Leve corça, alva gazela

Dos Cantos de Salomão!" (Idem: p. 64).

A atribuição de uma grande beleza a Maria chama a atenção, uma vez que não há qualquer referência a esse aspecto da mãe de Cristo nos Evangelhos. Desta forma, é plausível afirmar que a valorização da origem judaica de Maria dá-se através do mito da beleza da mulher bíblica, referido anteriormente. Nota-se que a beleza de Maria é elaborada a partir de uma comparação com imagens presentes no livro bíblico Cântico dos cânticos.

Interpreto como uma valorização da origem judaica de Maria o fato de sua imagem ser associada a um modelo oriundo da Bíblia Judaica. Mas, ao mesmo tempo, sua beleza é enaltecida, no trecho comentado, como superior a esse mesmo modelo. Neste último caso, poder-se-ia dizer que a caracterização da beleza de Maria no poema de Fagundes Varela representaria a superioridade de um modelo de beleza da mulher cristã em relação a um modelo de beleza da mulher bíblica.

\section{Conclusão}

Apesar de se verificarem ambigüidades, oriundas de um engajamento religioso, mesmo na caracterização, que qualifiquei como positiva, de duas das três figuras judias presentes nos excertos comentados neste trabalho, insisto que é notável

\footnotetext{
se estudar a transmissão dos temas românticos europeus para o Brasil é necessária uma pesquisa de literatura comparada. Essa minha postura se apóia em uma consideração de Antonio Candido no prefácio ao livro de Onédia Barbosa a respeito das traduções de Byron no Brasil. Lá seu autor assevera que para se estudar nossa literatura não se pode dispensar o comparativismo, pois estamos muito ligados à literatura européia (1975: 9). A não ser que o "estado dos nossos conhecimentos" (expressão dele) já tenha chegado, em 2007, a um desenvolvimento que dispense o comparativismo.
} 
que tais caracterizações se dêem em um contexto cristão. Desta forma, farei um esforço, no fim deste trabalho, para valorizar o tratamento positivo dessas duas figuras. No caso do rabino retratado por Junqueira Freire, penso que, se se abstrair o processo de desistoricização do Antigo Testamento levado a cabo por determinada tradição interpretativa cristã (ver acima), é plausível afirmar que o Antigo Testamento sugeriu e sugere aos cristãos conhecedores do texto bíblico uma força épica praticamente ausente no texto do Novo Testamento. Este, por sua vez, seria mais espiritualizado, mais centrado no drama individual da Redenção do que no espetáculo do mundo. Quer dizer: o Antigo Testamento, principalmente em livros de caráter mais explicitamente histórico como Gênesis, Exodo, Josué, Juízes, I e II Samuel, I e II Reis, I e II Crônicas dos Reis e Ester, supriria a imaginação cristã de um conteúdo espetacular, que pode beirar o grotesco, como grandes batalhas (livro de Josué), encenação de paixões que levam à vida (Jacó e Raquel) e à morte (Davi, Bat-Sebá e Urias), enfim, vicissitudes do homem carnal e histórico de uma nação que busca cumprir seu destino ético-religioso.

Já no caso de Maria, mãe de Cristo, creio que sua caracterização positiva a partir de um modelo de mulher judia, construído principalmente com base nos textos do Antigo Testamento, seria também estimulada por essa atração cristã pelo espetáculo do mundo que boa parte da Bíblia Judaica proporciona. Por outro lado, assumindo-se Maria como encarnação do feminino, elemento de determinado imaginário estético-emocional masculino, a identidade judaica de Maria seria interpretada pelo escritor como um elemento de exotismo. Isto é: o feminino em Maria reforçaria o caráter de singularidade, de diferença de sua identidade étnica.

\section{Bibliografia:}

AUERBACH, Erich. "Figura". In: Figura. São Paulo: Ática, 1997, p. 13-64.

CANDIDO, Antonio. "Prefácio". In: BARBOSA, Onédia Célia de Carvalho. Byron no Brasil: traduções. São Paulo: Ática, 1975, p. 9-13.

CORRÊIA, Frederico José (1817-1881). Inspirações poéticas. Maranhão: Typ. De J. A. G. Magalhães, 1848, 339 (i.e. 253) [4] p [errors in paging: no. 167-176, 201-254, 281-300, 305-306].

. Inspirações poéticas. 2a edição. Maranhão: Antonio Pereira Ramos D'almeida, 1868.

DELFINO, Luiz. Poesia completa. Organização, estudo e bibliografia por Lauro Junkes. Revisão e atualização lingüística: Lauro Junkes e Terezinha Kuhn Junkes. Florianópolis: Academia Catarinense de Letras, 2001, 736 p, tomos I e II. 
DUNN, James D. G. A teologia do Apóstolo Paulo. Tradução de Edwino Royer. São Paulo: Paulus, 2003 (Biblioteca de estudos bíblicos).

FREIRE, Junqueira. Poesias Completas de Junqueira Freire. Edição rigorosamente revista, com um estudo de Roberto Alvim Correa. Rio de Janeiro: Zélio Valverde, 1944, 223 p, volume I (Coleção "Grandes Poetas do Brasil”).

LAFER, Celso. "O judeu em Gil Vicente”. In: Gil Vicente e Camões. São Paulo: Ática, 1978. (Ensaio, n. 50).

MARCZYK, Marta Bernadete Frolini de Aguiar. Representações cristãs de tipos judeus em As minas de prata, de José de Alencar. Dissertação de mestrado apresentada ao Programa de Pós-Graduação da Faculdade de Filosofia, Letras e Ciências Humanas da Universidade de São Paulo. São Paulo, 2006.

PRAZ, Mario. A carne, a morte e o diabo na literatura romântica. Tradução de Philadelpho Menezes a partir de La carne, la morte e il diavolo nella letteratura romantica. Campinas, SP: Editora da Unicamp, 1996 (Coleção Repertórios).

VARELA, Luís Nicolau Fagundes. Dispersos, e pela primeira vez em livro, poesia, prosa. São Paulo: Conselho Estadual de Cultura, [1970] (Coleção Textos e documentos, n. 12)

VÁRIOS. A Bíblia de Jerusalém. [2a edição]. São Paulo: Paulus, [1985]. 